\title{
Fluorescent carbazolylurea anion receptors
}

\author{
Jennifer R. Hiscock, ${ }^{a}$ Claudia Caltagirone, ${ }^{\mathrm{b}}$ Mark E. Light ${ }^{\mathrm{a}}$, Michael B. Hursthouse and Philip A. Gale*,a \\ Received (in $X X X, X X X) X$ th $X X X X X X X X X 200 X$, Accepted $X$ th $X X X X X X X X X 200 X$ \\ First published on the web $X$ th $X X X X X X X X X 200 X$ \\ ${ }_{5}$ DOI: 10.1039/b000000x
}

\begin{abstract}
A series of fluorsecent carbazolylurea base anion receptors have been synthesised that show a high affinity for oxo-anions (particularly bicarbonate and acetate). The fluorescence of dicarbazolylurea (1) is quenched upon addition of benzoate 10 anions in DMSO/0.5\% water.
\end{abstract}

Our interest in anion complexation ${ }^{1}$ has led us to investigate compounds that are easy to make and yet have high affinities and selectivities for anionic guests. ${ }^{2}$ Work from the groups of Jeong, ${ }^{3}$ Jurczak, ${ }^{4}$ Beer, ${ }^{5}$ Sessler, ${ }^{6}$ Pfeffer ${ }^{7}$ and ourselves ${ }^{8}$ has 15 shown that indoles, carbazoles, indolocarbazoles and biindoles are effective components of hydrogen bond donating anion receptors. ${ }^{9}$ In a recent collaboration with Albrecht, we found that 2,7-disubstituted indoles were effective receptors for carboxylates. ${ }^{10}$ Building on this work, we discovered that 20 diindolylurea compounds have very high affinities for oxoanions and selectively bind dihydrogen phosphate in DMSO/water mixtures. ${ }^{11}$ In this communication we report the synthesis and anion binding properties of related carbazolylureas (1-3). In addition to forming strong ${ }_{25}$ complexes with oxoanionic guests, the fluorescence of these easy to make receptors is perturbed in the presence of anions, allowing them to be employed as fluorescent anion sensors. ${ }^{12}$

1-Nitrocarbazole was synthesised via a modification to a literature procedure (see ESI). ${ }^{13}$ This was then reduced with 30 hydrogen over $10 \% \mathrm{Pd} / \mathrm{C}$ to afford the 1-aminocarbazole. This compound was then dissolved in a mixture of dicholomethane and a saturated aqueous solution of $\mathrm{NaHCO}_{3}$ and one equivalent of triphosgene added to afford the isocyanate in quantitative yield. This compound proved to be 35 very reactive and hence was used immediately. Compounds $\mathbf{1}$, 2 were synthesised in 41 and $26 \%$ respective yields by addition of a solution of the isocyanate in dichloromethane to a solution of 1-aminocarbazole or 7-aminoindole and triethylamine in chloroform. Compound $\mathbf{3}$ was prepared in $4069 \%$ yield by addition of a solution of phenylisocyanate in dichloromethane to a solution of 1-aminocarbazole in dichloromethane.

Anion complexation studies were performed using ${ }^{1} \mathrm{H}$ NMR titration techniques in DMSO- $d_{6} / 0.5 \%$ water with stability ${ }_{45}$ constants obtained from the titration curves using the EQNMR computer program. ${ }^{14}$ The results show that all the compounds bind acetate strongly. NMR titrations with dihydrogen phosphate show strong binding but the titration curves for compounds 1 and 2 show features at 1 and 2 equivalents of ${ }_{50}$ anion that cannot be fitted adequately to a binding model (see ESI). Titrations with fluoride caused broadening of the $\mathrm{NH}$ resonances in all cases thus it was not possible to determine an accurate stability constant. Shifts of the NH resonances suggest weak complex formation (i.e. a continuous downfield ${ }_{55}$ shift - see ESI for compounds 2 and 3 ). Binding studies were also conducted with tetraethylammonium bicarbonate. Strong binding was observed in all cases with stability constants > $10^{4} \mathrm{M}^{-1}$.
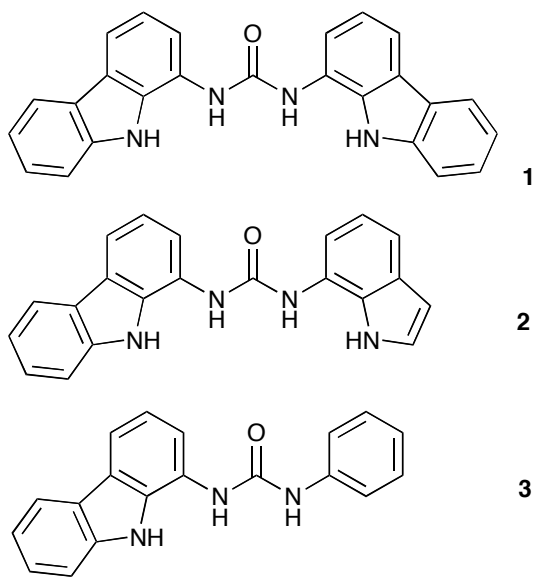

3

Table 1 The stability constants $\left(\mathrm{M}^{-1}\right)$ of compounds $\mathbf{1}, \mathbf{2}$ and $\mathbf{3}$ with a variety of anionic guests (added as tetrabutylammonium salts except bicarbonate which was added as a tetraethylammonium salt) at $298 \mathrm{~K}$ in DMSO- $d_{6} / 0.5 \%$ water as determined by following urea NH resonance 65 adjacent to the carbazole. In all cases 1:1 receptor: anion stoichiometry was observed. Errors estimated to be no more than $\pm 15 \%$

\begin{tabular}{|c|c|c|c|}
\hline $\begin{array}{l}\text { Anion } \\
\text { acetate }\end{array}$ & $\begin{array}{l}\text { Compound } 1 \\
>10^{4}\end{array}$ & $\begin{array}{l}\text { Compound } 2 \\
>10^{4}\end{array}$ & $\begin{array}{l}\text { Compound } 3 \\
>10^{4}\end{array}$ \\
\hline benzoate & 5670 & 5880 & 3420 \\
\hline $\begin{array}{l}\text { dihydrogen } \\
\text { phosphate }\end{array}$ & a & a & 6140 \\
\hline chloride & $\begin{array}{l}102 \\
>10^{4}\end{array}$ & $\begin{array}{l}139 \\
>10^{4}\end{array}$ & $\begin{array}{l}85 \\
>10^{4}\end{array}$ \\
\hline
\end{tabular}

a NMR titration curve could not be fitted to a $1: 1$ or $1: 2$ receptor:anion binding stoichimetry but indicates strong 70 binding.

Crystals of the acetate complex of compound $\mathbf{1}$ were grown by slow evaporation of a DMSO solution of the receptor in the presence of excess tetrabutylammonium 75 acetate.t The structure (shown in Figure 1) reveals that the receptor binds acetate via four $\mathrm{NH}^{\cdots} \mathrm{O}$ hydrogen bonds

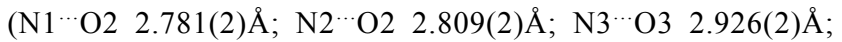
$\mathrm{N} 4 \cdots \mathrm{O} 32.820(2))$. One of the carbazoles is in the plane of the urea group whilst the other twists out of plane by $39.9^{\circ}$. 

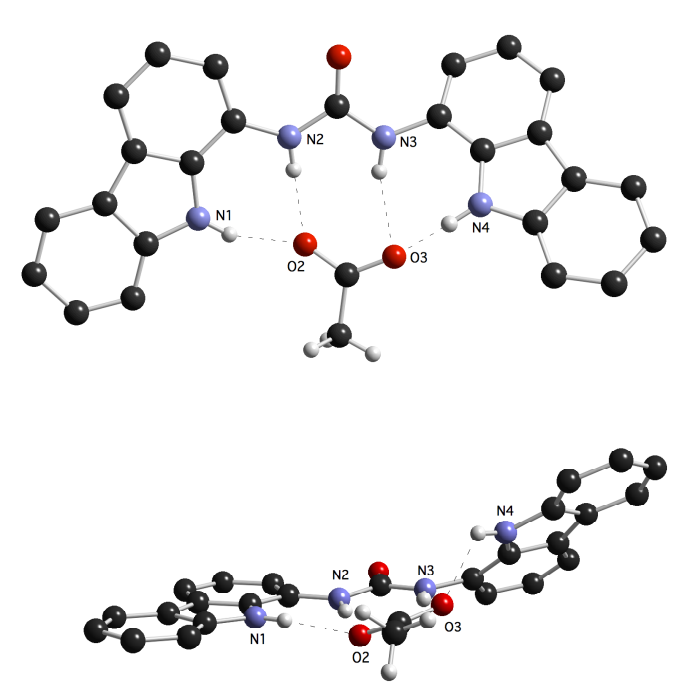

5 Figure 1 Two views of the X-ray crystal structure of the acetate complex of receptor 1. Tetrabutylammonium counter cation and selected hydrogen atoms have been omitted for clarity.

Crystals of the benzoate complex of compound 1 were grown 10 by slow evaporation of a DMSO solution of the receptor in the presence of excess tetrabutylammonium benzoate. The unit cell contains two crystallographically distinct benzoate complexes which adopt similar conformations. One example is shown in Figure 2. As with the acetate complex, in both 15 benzoate complexes one of the carbazoles is in the plane of the urea whilst the other is twisted out of plane by $37.1^{\circ}$ or $43.0^{\circ}$. Each benzaote anion is bound by four hydrogen bonds in the range $\mathrm{N}^{\cdots \cdots} \mathrm{O} 2.762(5)-2.996(5) \AA$.
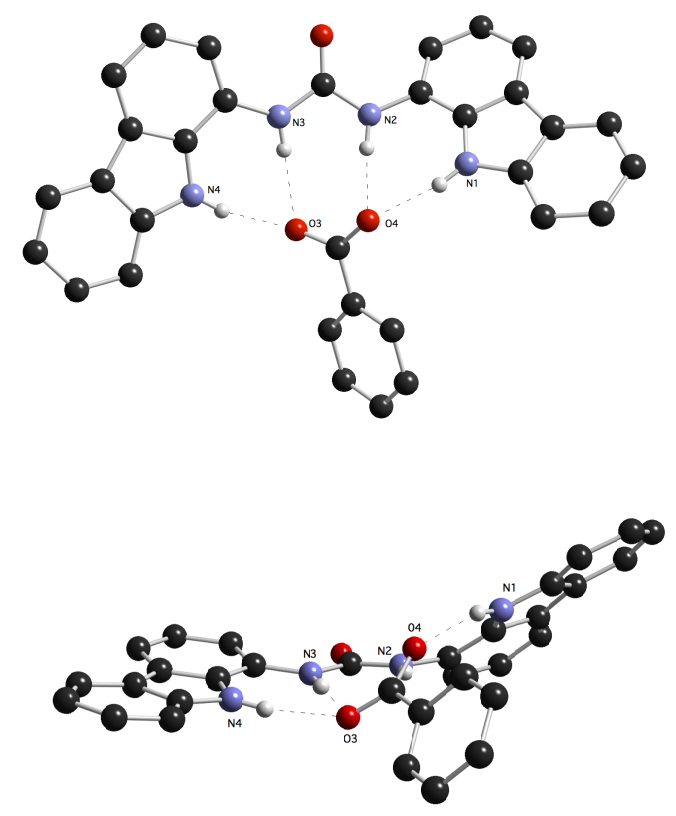

Figure 2 Two views of the X-ray crystal structure of one of the two crystallographically distinct benzoate complexes present in the unit cell of the tetrabutylammonium benzoate complex of receptor $\mathbf{1}$. Tetrabutylammonium counter cations and selected hydrogen atoms have been omitted for clarity.

In order to investigate the ability of receptors $\mathbf{1 - 3}$ to act as luminescent sensors, fluorescence studies were performed in a $\mathrm{DMSO} / 0.5 \%$ water mixture. Under these conditions receptor 1 shows an intense fluorescent emission $(\Phi=0.549)$ with 30 maxima at $363 \mathrm{~nm}$ and $376 \mathrm{~nm}$ when excited at $270 \mathrm{~nm}$. As shown in Fig. 3 upon addition of increasing amounts of tetrabutylammonium benzoate, a selective quenching of the fluorescent emission was observed $\left(I_{\text {res }}=10 \%\right)$.

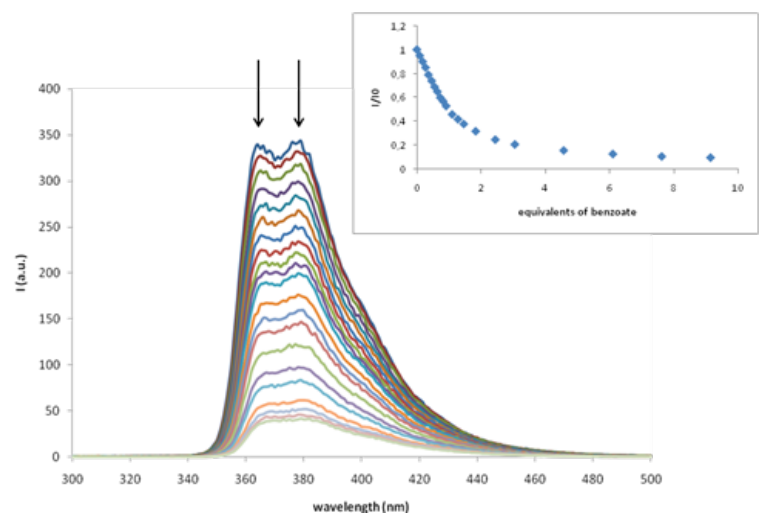

Figure 3 Fluorescent quenching of receptor 1 in DMSO/0.5\% water upon addition of increasing amounts of tetrabutylammonium benzoate.

Upon addition of the tetrabutylammonium salts of acetate, fluoride chloride, dihydrogen phosphate and the 40 tetraethylammonium salt of bicarbonate less dramatic effects were observed as shown in Fig. 4. In fact, only acetate caused a partial quenching of the emission $\left(I_{\text {res }}=50 \%\right)$ while a stronger quenching upon addition of fluoride was observed but only when an excess of anion was added (more than three 45 equivalents) which may be indicative of deprotonation. ${ }^{15} \mathrm{~A}$ slight perturbation of the fluorescent emission of $\mathbf{1}$ was observed in the presence of dihydrogen phosphate $\left(I_{\text {res }}=68 \%\right)$ and bicarbonate $\left(I_{\text {res }}=73 \%\right)$. Chloride did not effect the emission of the system. The trend in fluorescence quenching ${ }_{50}$ is similar to that found for the stability constants by ${ }^{1} \mathrm{H}-\mathrm{NMR}$ titrations with the exception for benzoate. This may be due to a $\pi-\pi$ interaction in the excited state between the aromatic electrons of the carbazole moieties and the substrate.

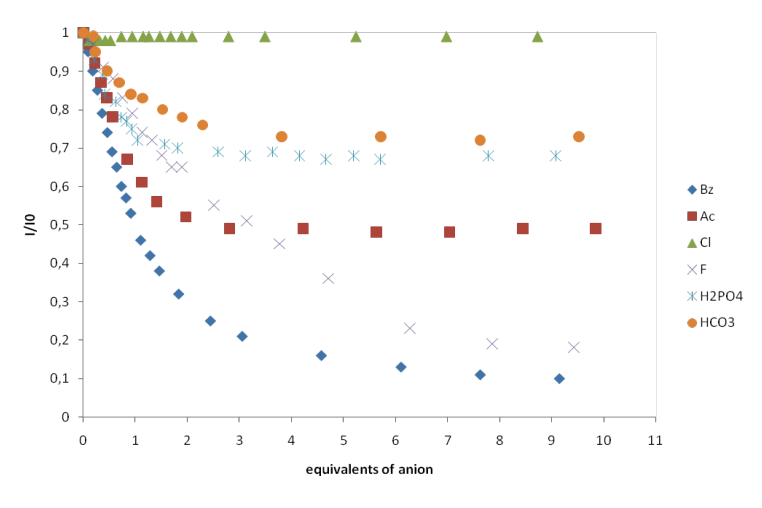


Figure 4 Effect of increasing anion concentration upon the relative fluorescence emission of receptor 1 in DMSO/0.5\% water.

Similar, but less pronounced quenching effects caused by benzoate were observed with receptor $2(\Phi=0.562$ and $3(\Phi$ $\left.{ }_{5}=0.501\right)$ (see ESI). Thus, under these conditions receptor 1 acts as a selective ON-OFF fluorescent sensor for benzoate. Compounds $\mathbf{1}-\mathbf{3}$ are easy-to-make analogues of the diindolylureas binding acetate and bicarbonate strongly. The fluorescence of compound $\mathbf{1}$ is selectively quenching by 10 benzoate. We are continuing to explore the anion complexation and sensing properties of indole and carbazole ureas. The results of these studies will be reported in due course.

\section{Acknowledgements}

15 P.A.G. thanks the EPSRC for a DTA studentship (JRH). C.C. would like to thank the Italian Ministero dell'Istruzione, dell'Università e della Ricerca Scientifica (MIUR) for financial support (Project PRIN-2007C8RW53).

\section{Notes and references}

${ }_{20}{ }^{a}$ School of Chemistry, University of Southampton, Southampton, SO17 IBJ, UK. Fax: 0238059 6805; Tel: 023 8059 3332; E-mail: philip.gale@soton.ac.uk

${ }^{b}$ Dipartimento di Chimica Inorganica ed Analitica, Università degli Studi di Cagliari, S.S. 554 Bivio per Sestu, 09042 Monserrato (CA), Italy. Fax:

25 +390706754456; Tel: +390706754452; E-mail: ccaltagirone@unica.it. $\dagger$ Electronic Supplementary Information (ESI) available: [details of any supplementary information available should be included here]. See DOI: $10.1039 / \mathrm{b} 000000 \mathrm{x} /$

30 \$ Crystal data were collected on a Bruker Nonius KappaCCD with a Mo rotating anode generator; standard procedures were followed. Crystal data for compound 1.tetrabutylammoniuma acetate: $\mathrm{C}_{43} \mathrm{H}_{57} \mathrm{~N}_{5} \mathrm{O}_{3}, \mathrm{Mr}=691.94$, $\mathrm{T}=120(2) \mathrm{K}$, monoclinic, space group $P 2_{1} / n, \quad a=11.0933(2), b=$ 26.7833(6), $c=13.2013(3) \AA, \beta=98.0560(10)^{\circ}, V=3883.60(14) \AA^{3}, \rho_{\text {calc }}$ $35=1.183 \mathrm{~g} \mathrm{~cm}^{-3}, \mu=0.075 \mathrm{~mm}^{-1}, \mathrm{Z}=4$, reflections collected: 40088 , independent reflections: $8914\left(R_{\text {int }}=0.0815\right)$, final $R$ indices $[I>2 \sigma I]: R 1$ $=0.0674, w R 2=0.1354, R$ indices (all data): $R 1=0.1274 . w R 2=0.1613$.

- Crystal data for compound 1.tetrabutylammoniuma benzoate: ${ }_{40} \mathrm{C}_{48} \mathrm{H}_{59} \mathrm{~N}_{5} \mathrm{O}_{3}, \mathrm{Mr}=754.00, \mathrm{~T}=120(2) \mathrm{K}$, triclinic, space group $P 1$ $=10.980(5), \quad b=13.774(5), \quad c=15.173(5) \quad \AA, \alpha=68.760(5)^{\circ}, \quad \beta$ $=85.232(5)^{\circ}, \gamma=81.541(5)^{\circ}, V=2114.5(14) \AA^{3}, \rho_{\text {calc }}=1.184 \mathrm{~g} \mathrm{~cm}^{-3}, \mu=$ $0.074 \mathrm{~mm}^{-1}, \mathrm{Z}=2$, reflections collected: 44837 , independent reflections: $9728\left(R_{\text {int }}=0.1052\right)$, final $R$ indices $[I>2 \sigma I]: R 1=0.0661, w R 2=0.1368$, ${ }_{45} R$ indices (all data): $R 1=0.1190 . w R 2=0.1589$.

1. C. Caltagirone and P.A. Gale, Chem. Soc. Rev. 2009, 38, 520563; P.A. Gale, S.E. García-Garrido and J. Garric, Chem. Soc. Rev. 2008, 37, 151-190; P. Prados and R. Quesada, Supramol. Chem. 2008, 20, 201-216; J.L. Sessler, P.A. Gale and W.S. Cho, Anion Receptor Chemistry (Monographs in Supramolecular Chemistry) Ed. J.F. Stoddart; Royal Society of Chemistry, Cambridge, 2006; P.A. Gale and R. Quesada, Coord. Chem. Rev. 2006, 250, 329-3244; P.A. Gale, Acc. Chem. Res. 2006, 39, 465-475; K. Bowman-James, Acc. Chem. Res. 2005, 38, 671-678; F.P. Schmidtchen and M. Berger, Chem. Rev. 1997, 97, 1609-1646.

2. S.J. Brooks, S.E. García-Garrido, M.E. Light, P.A. Cole and P.A. Gale, Chem. Eur. J. 2007, 13, 3320-3329; P.V. Santacroce, J.T. Davis, M.E. Light, P.A. Gale, J.C. IglesiasSanchez, P. Prados and R. Quesada, J. Am. Chem. Soc. 2007, 129, 1886-1887; J.L. Sessler, D.E. Gross, W.-S. Cho, V.M.
Lynch, F.P. Schmidtchen, G.W. Bates, M.E. Light and P.A. Gale, J. Am. Chem. Soc. 2006, 128, 12281-12288; S.J. Brooks, P.A. Gale and M.E. Light Chem. Commun. 2006, 4344-4346; S.J. Brooks, P.A. Gale and M.E. Light, Chem. Commun., 2005, 4696-4698.

3. K.-J. Chang, B.-N. Kang, M.-H. Lee and K.-S. Jeong, J. Am. Chem. Soc. 2005, 127, 12214; J.Ju, M. Park, J.-m. Suk, M.S. Lah and K.-S. Jeong, Chem. Commun. 2008, 3546-3548; J.-m. Suk, M. K. Chae, N.-K. Kim, U.-1 Kim and K.-S. Jeong, Pure Appl. Chem. 2008, 80, 599-608.

4. M.J. Chmielewski, M. Charon and J. Jurczak, Org. Lett. 2004, 6, 3501-3504; T. Zielínski, P. Dydio and J. Jurczak, Tetrahedron 2007, 64, 568-574.

5. M.J. Chmielewski, L. Zhao, A. Brown, D. Curiel, M.R. Sambrook, A.L. Thompson, S.M. Santos, V. Felix, J.J. Davis and P.D. Beer, Chem. Commun. 2008, 3154-3156

6. P. Piatek, V.M. Lynch and J. L. Sessler, J. Am. Chem. Soc. 2004, 126, 16073-16076.

7. F.M. Pfeffer, K.F. Lim and K.J. Sedgwick, Org. Biomol. Chem. 2007, 5, 1795-1799.

8. G.W. Bates, P.A. Gale and M.E. Light, Chem. Commun. 2007, 2121-2123.

9. P.A. Gale, Chem. Commun. 2008, 4525-4540.

10. G.W. Bates, Triyanti, M.E. Light, M. Albrecht and P.A. Gale, J. Org. Chem. 2007, 72, 8921-8927.

11. C. Caltagirone, P.A. Gale, J.R. Hiscock, S.J. Brooks, M.B. Hursthouse and M.E. Light, Chem. Commun. 2008, 30073009; C. Caltagirone, J.R. Hiscock, M.B. Hursthouse, M.E. Light and P.A. Gale, Chem. Eur. J., 2008, 14, 10236-10243.

12. For examples of other related fluorescent anion sensors see: D. Curiel, A. Cowley and P.D. Beer, Chem. Commun. 2005, 236238; T.D. Thangadurai, N.J. Singh, I.-C. Hwang, J.W. Lee, R.P. Chandran and K.S. Kim, J. Org. Chem. 2007, 72, 54615464; G-y. Qing, Y.-B. He, F. Wang, H.-J. Qin, C.-G. Hu and X. Yang, Eur. J. Org. Chem. 2007, 1768-1778.

13. E. Merisor and U. Beifuss, Tetrahedron Letters 2007, 48, 8383-8387.

14. M.J. Hynes, J. Chem. Soc. Dalton Trans. 1993, 311-312.

15. C.I. Lin, S. Selvi, J.-M. Fang, P.-T. Chou, C.-H. Lai, and Y.M. Cheng, J. Org. Chem. 2007, 72, 3537-3542; for other examples of anion triggered deprotonation see: S. Camiolo, P. A. Gale, M. B. Hursthouse, M. E. Light and A. J. Shi, Chem. Commun. 2002, 758; P.A. Gale, K. Navakhun, S. Camiolo, M.E. Light and M.B. Hursthouse, J. Am. Chem. Soc. 2002, 124, 11228; S. Camiolo, P.A. Gale, M.B. Hursthouse and M.E. Light, Org. Biomol. Chem. 2003, 1, 741; L.S. Evans, P.A. Gale, M.E. Light and R. Quesada, Chem. Commun. 2006, 965967; L.S. Evans, P.A. Gale, M.E. Light and R. Quesada, New J. Chem., 2006, 30, 1019-1025.T. Gunnlaugsson, P. E. Kruger, P. Jensen, F. M. Pfeffer and G. M. Hussey, Tetrahedron Lett., 2003, 44, 8909; A. M Costero, M. J. Banuls, M. J Aurell, M. D. Ward and S. Argent, Tetrahedron 2004, 60, 9471; M. Boiocchi, L. Del Boca, D. Esteban-Gómez, L. Fabbrizzi, M. Licchelli and E. Monzani, J. Am. Chem. Soc., 2004, 126, 16507; D. Esteban-Gómez, L. Fabbrizzi and M. Licchelli, J. Org. Chem. 2005, 70, 5717; M. Boiocchi, L. Del Boca, D. Esteban-Gómez, L. Fabbrizzi, M. Licchelli and E. Monzani, Chem. Eur. J., 2005, 11, 3097; D. Esteban-Gómez, L. Fabbrizzi, M. Licchelli and E. Monzani, Org. Biomol. Chem., 2005, 3, 1495 . 


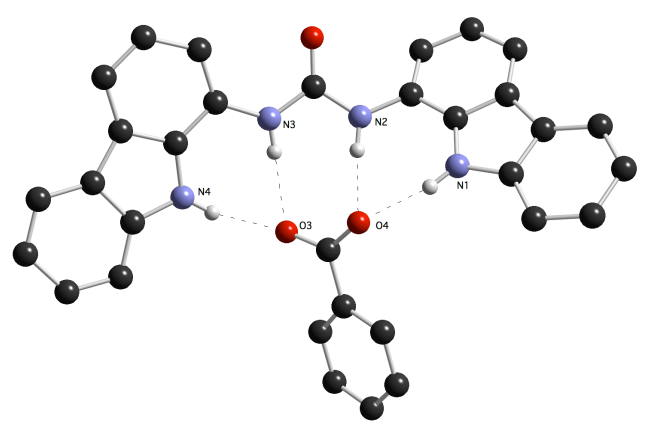

